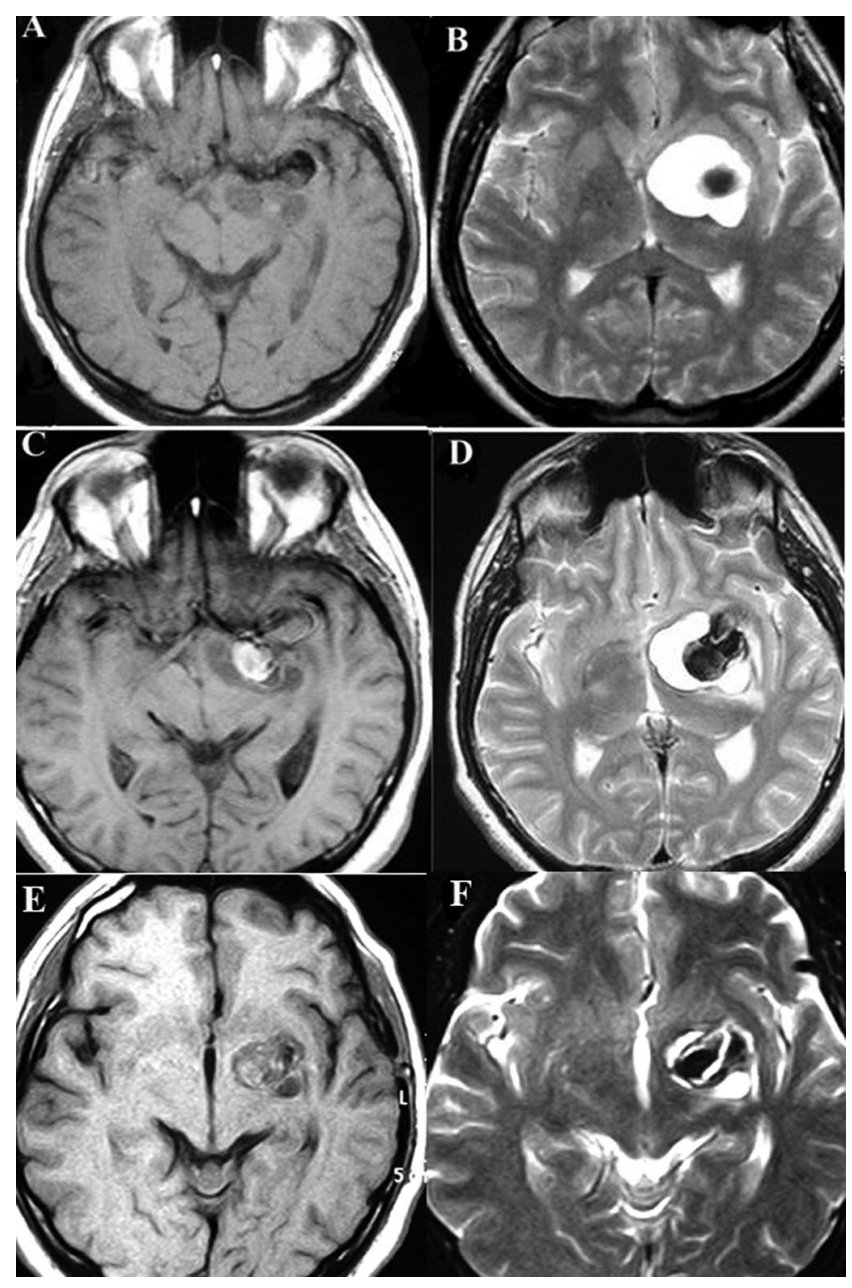

Figure 1. MRI at presentation showing a partially thrombosed middle cerebral artery giant aneurysm compressing the left basal ganglia (A: axial T1WI, B: axial T2WI) and 6 years later (C: axial T1WI, and D: axial T2WI). The second MRI examination $(C, D)$ shows an increase of the size of the aneurysm. Postoperative $M R I(E, F)$ reveals a decrease of the aneurysm volume resulting in less compression of the basal ganglia.

\section{VIDEO Aneurysm presenting as parkinsonism}

Sevasti Bostantjopoulou, MD; Zoe Katsarou, MD;

Anastasios Petridis, MD; and Alexandros Andreou, $M D$,

Thessaloniki, Greece (S.B., Z.K., A.P.); Athens, Greece (A.A.)

A 25-year-old man presented with a 3-month history of gradually progressive right side hemiparkinsonism. On examination

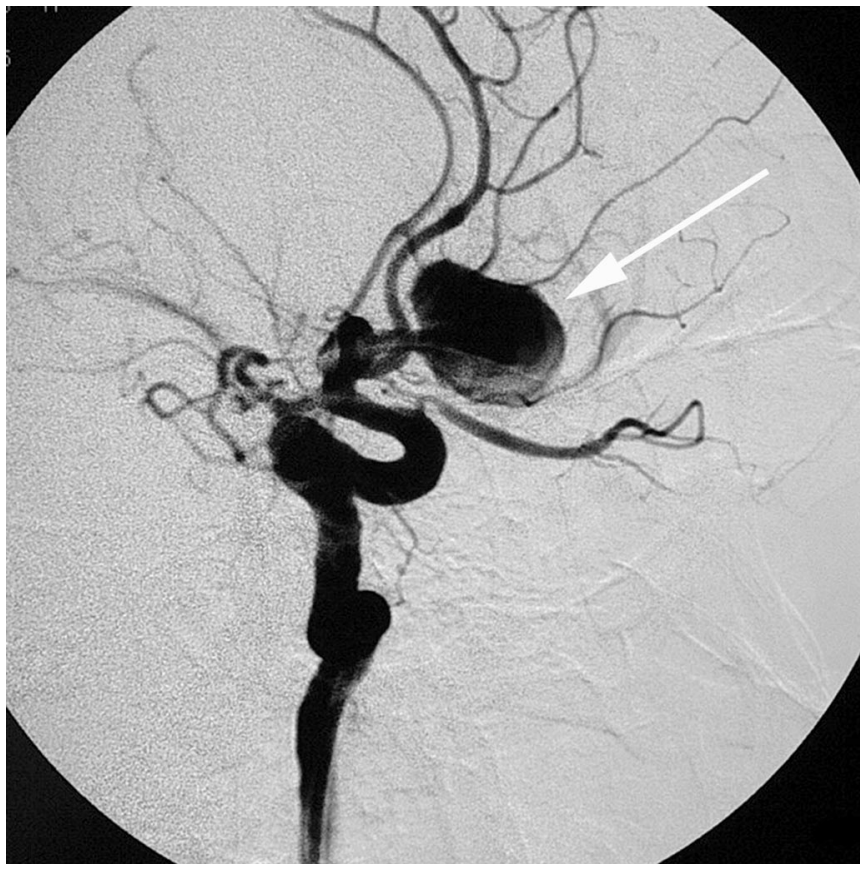

Figure 2. Digital subtraction angiography shows a giant aneurysm of the left middle cerebral artery (arrow).

his Unified Parkinson Disease Rating Scale motor score was 12 on the right side. There were no other abnormal neurologic findings. Brain MRI and angiography showed a giant thrombus containing aneurysm of the left middle cerebral artery compressing the left basal ganglia (figures 1 and 2). Initially the patient refused neurosurgical intervention. At follow-up 6 years later his neurologic status remained unchanged (video E-1). The patient underwent surgery in December 2005 and his hemiparkinsonism was almost abolished (video E-2). Secondary parkinsonism resulting from unruptured giant aneurysms is rare. A patient with parkinsonism due to a giant middle cerebral aneurysm which was abolished after surgical excision of the aneurysm has been reported, ${ }^{1}$ but there is another case in the literature with asymmetric parkinsonism, due to internal carotid artery aneurysm, which did not improve after internal carotid artery ligation. ${ }^{2}$

1. Gross M. Giant cerebral aneurysm presenting as hemiparkinsonism. J Neurol Neurosurg Psychiatry 1987;50:1075.

2. Sibon I, Rajabally Y, Tison F. Parkinsonism as a result of a giant aneurysm. Mov Disord 1999;14:159-161.
Additional material related to this article can be found on the Neurology Web site. Go to www.neurology.org and scroll down the Table of Contents for the December 12 issue to find the title link for this article.

\section{Disclosure: The authors report no conflicts of interest.}

Address correspondence and reprint requests to Dr. Sevasti Bostantjopoulou, 9 Navarinou Square, Gr 54622, Thessaloniki, Greece; e-mail: bostkamb@otenet.gr 


\section{Neurology}

\section{Aneurysm presenting as parkinsonism \\ Sevasti Bostantjopoulou, Zoe Katsarou, Anastasios Petridis, et al. \\ Neurology 2006;67;2028}

DOI 10.1212/01.wnl.0000232726.76501.09

\section{This information is current as of December 11, 2006}

\section{Updated Information \& Services}

Supplementary Material

\section{References}

Subspecialty Collections

Permissions \& Licensing

Reprints including high resolution figures, can be found at: http://n.neurology.org/content/67/11/2028.full

Supplementary material can be found at: http://n.neurology.org/content/suppl/2006/12/11/67.11.2028.DC1 http://n.neurology.org/content/suppl/2012/04/16/67.11.2028.DC2

This article cites 2 articles, 1 of which you can access for free at: http://n.neurology.org/content/67/11/2028.full\#ref-list-1

This article, along with others on similar topics, appears in the following collection(s):

\section{MRI}

http://n.neurology.org/cgi/collection/mri

Parkinson's disease/Parkinsonism

http://n.neurology.org/cgi/collection/parkinsons_disease_parkinsonism Subarachnoid hemorrhage

http://n.neurology.org/cgi/collection/subarachnoid_hemorrhage

Information about reproducing this article in parts (figures,tables) or in its entirety can be found online at:

http://www.neurology.org/about/about_the_journal\#permissions

Information about ordering reprints can be found online:

http://n.neurology.org/subscribers/advertise

Neurology ${ }^{\circledR}$ is the official journal of the American Academy of Neurology. Published continuously since 1951, it is now a weekly with 48 issues per year. Copyright . All rights reserved. Print ISSN: 0028-3878. Online ISSN: 1526-632X.

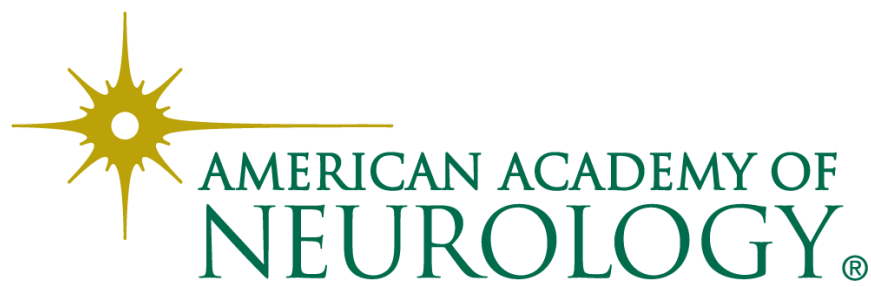

